DOI 10.31558/2307-2318.2019.4.7

УДК 37.013 .74

Ахновська I.O., к.е.н., доцент, доцент кафедри підприємництва, корпоративної та просторової економіки Донецького національного університету імені Василя Стуса

\title{
ВІДКРИТА ТА НЕФОРМАЛЬНА ОСВІТА: КОМПАРАТИВНИЙ АНАЛІЗ
}

У статті представлені результати порівняльного аналізу відкритої та неформальної освіти. Метою статті є дослідження та узагальнення теоретичних підходів до визначення понять «неформальна освіта» та «відкрита освіта». Проаналізовано наукові публікації вітчизняних та зарубіжних вчених. Доведено, що ці поняття трактуються українською науковою спільнотою по-різному. Відображено історичні передумови появи відкритої освіти та виокремлено етапи іiі становлення. У статті проаналізовано істотні характеристики відкритої освіти. Розкрито причини, що вплинули на процес розвитку відкритої освіти. Визначено тенденції відкритої освіти в сучасних умовах. Зазначено, що відкрита освіта є невід'ємною складовою інформатизації суспільства. Крім того, здійснено узагальнення наукової літератури для порівняння позиції вчених щодо сутності поняття «неформальна освіта», яка є важливою частиною концепції «навчання протягом усього життя». Тим самим воно привертає увагу іноземних організацій, міжнародних та вітчизняних вчених. Визначення неформальної освіти означає процес індивідуального набуття знань і вмінь поза формальною освітньою системою. Також визначено, що неформальна освіта має деякі особливості - вона організовується, планується, підтримується і, як правило, не кваліфікується. У статті реалізовано синтез наукової літератури щодо поняття «неформальна освіта», досліджено генезис використання цього поняття, висвітлено основні тенденції неформальної освіти, а також проблеми розвитку неформальної освіти. Слід зазначити, що розвиток неформальної освіти тісно пов'язаний з інноваційною моделлю формування суспільства. Подальше дослідження та розвиток відкритої та неформальної освіти, а також їх інтеграція до формальної освіти дозволять Україні підвищити ефективність національної економіки в умовах переходу до економіки знань. Методи дослідження: аналіз, синтез, узагальнення і систематизація науково-теоретичних положень.

Ключові слова: відкрита освіта, неформальна освіта, компаративний аналіз, економіка знань, техноглобалізм.

Табл. - 4, Літ. - 27.

\section{Ахновская И.А. ОТКРЫТОЕ И НЕФОРМАЛЬНОЕ ОБРАЗОВАНИЕ: КОМПАРАТИВНЫЙ АНАЛИЗ}

В статье представлены результаты компаративного анализа открытого и неформального образования. Целью статьи является исследование и обобщение теоретических подходов к определению понятий «неформальное образование» и «открытое образование». Проанализированы научные публикации отечественных и зарубежных исследователей, доказано, что эти понятия трактуются украинскими учёными по-разному. Рассмотрены исторические предпосылки появления открытого образования, выделены этапы его становления. Проанализированы характерные особенности открытого образования. Выявлены причины, влияющие на развитие открытого образования. Определены тенденции открытого образования в современных условиях. Определено, что открытое образование является неотъемлемой частью информатизации общества. Кроме того, в статье осуществлено обобщение научной 
литературы для сравнения позиции ученых относительно содержания понятия «неформальное образование», которое является важнейшей составляющей концепции «непрерывное обучение». Тем самым оно привлекает внимание иностранных организаций, международных и отечественных учёных. Определение неформального образования означает процесс индивидуального приобретения знаний и умений вне формальной образовательной системы. Также определено, что неформальное образование имеет определённые особенности - оно организовывается, планируется, поддерживается и, как правило, не предполагает получение документа. В статье реализован синтез научной литературы относительно понятия «неформальное образование», исследован генезис использования данного понятия, выделены основные тенденции организации неформального образования, а также проблемы его развития. Следует отметить, что развитие неформального образования тесно связано с инновационной моделью формирования общества. Дальнейшее исследование и развитие открытого и неформального образования, а также их интеграция в формальное образование позволят Украине повысить эффективность национальной экономики в условиях перехода к экономике знаний. Методы исследования: анализ, синтез, обобщение и систематизация научно-теоретических положений.

Ключевые слова: открытое образование, неформальное образование, компаративный анализ, экономика знаний, техноглобализм.

\section{Akhnovska I. \\ OPEN AND NON-FORMAL EDUCATION: COMPARATIVE ANALYSIS}

The article presents results of a comparative analysis of open and non-formal education. The aim of article is the researching and generalization of theoretical approaches to the definitions of "non-formal education" and "open education". The scientific publications of native and foreign researchers are analyzed. Proved, that the notions are treated by Ukrainian scientists differently. The historical background of the emergence of the category of "open education" is reflected. The paper analyzes the essential characteristics of open education.The article discovers the reasons that influenced the process of development of open education. The paper determines tendencies of open education in present conditions. In the publication is determined that open education is an integral part of the informational society. Non-formal education is an important part of "life-long learning"concept. Thereby it attracts attention of international organizations, international and domestic scientists. Non-formal education definition means the process of individual acquiring of knowledge and skills out of formal educational system. Non-formal education has some specific features - it is organized, planned, supported and as a rule doesn't qualify. In article the synthesis of scientific literature on the concept of "non-formal education" is implemented, the genesis of the use of this concept is investigated, the main trends of informal education are highlighted, the main problems of the development of non-formal education are outlined. It should be noted that non-formal education development is closely connected with innovational model of society development forming. Further investigation and development of open and non-formal education as well as their integration in formal education will allow Ukraine the opportunity to increase the efficiency of national economy under conditions to innovational model development transfer. Research methods: analysis, synthesis, generalization and systematization of scientific and theoretical provisions.

Key words: open education, non-formal education, comparative analysis, knowledge economy, technoglobalism. 
Постановка проблеми. У сучасних умовах переходу до економіки знань перед нашою країною постає низка проблем, зокрема - взаємодії формальної та неформальної освіти. Сутність неформальної освіти визначено в українському законодавстві, але щодо відкритої освіти не існує чіткої трактовки, дехто ототожнює ії з неформальною, дехто 3 дистанційною. За даними Міністерства соціальної політики, на постійній основі за межами України працює 3,2 млн. громадян, на тимчасовій основі - від 7 до 9 млн. осіб. У 2016-2017 навчальному році було 77424 особи з українським громадянством, які навчались у закордонних університетах. Якщо врахувати, що в українських ЗВО (університети, академії та інститути усіх форм власності) на денних програмах тоді навчалось приблизно 900 тис. осіб, то за кордоном навчалось близько 8\% від загальної кількості тих, хто вчиться на денних програмах вищої освіти. Найчастіше їдуть до Польщі, Росії, Німеччини, Канади, Чехії, Італії, США, Іспанії, Австрії, Франції, Словаччини [1]. За прогнозами Інституту демографії та соціальних досліджень Національної академії наук України, до 2031 року населення нашої країни скоротиться до 39,5 мільйонів осіб. Таким чином, одним з основних обов'язків держави, поряд із першочерговими завданнями щодо зміцнення національної безпеки, подолання економічної кризи, розбудови миру та соціальної злагоди залишається реінтеграція мігрантів. Крім того, у зв'язку з розвитком блогосфери, в останні роки поширеним $\epsilon$ тревел-блогерство. Діти таких батьків-блогерів, як правило, $\epsilon$ хоумскулерами i навчаються дистанційно. Великою проблемою $є$ також реінтеграція осіб, які проживають у Криму, Донецькій та Луганській областях. Одним з інструментів цього є механізм неформальної та відкритої освіти.

Аналіз останніх досліджень і публікацій. Роль відкритої освіти у суспільстві на сьогодні встановлено в роботах О. Захарова, І. Колеснікової, А. Хуторського, О.Висоцької, О. Коржилової, М. Лещенко, А. Яцишин. Спробу розглянути відкриту освіту як систему здійснено у наукових працях Р. Бужикова, Л. Виноградова, Б. Шуневича. Теоретичні аспекти неформальної освіти стали предметом вивчення у працях Ф. Кумбса, А. Гончарука, Л. Лук’янової, Л. Сігаєвої та інших. Теоретичні основи процесу дистанційного навчання розглядаються в роботах В. Кухаренко, Н. Морзе, В. Олійник, C. Полат, О. Рибалко та інших. Проблеми упровадження інформаційних i комунікаційних технологій у навчальний процес досліджують В. Биков, М. Жалдак, М. Кадемія та ін. Характерні особливості віртуальних комунікацій досліджено у наукових працях В. Слободяна, Г. Остапенко, О. Висоцької. Однак, слід констатувати, що питанням неформальної і відкритої освіти сьогодні приділяється достатньо мало уваги.

Формулювання мети статті. Реформування економіки неможливе без змін в освітньому процесі. На сьогодні немає одностайності серед науковців щодо визначення понять «відкрита освіта», «неформальна освіта», «альтернативна освіта», «віртуальні комунікації», «дистанційна освіта», «дистанційне навчання» та «е-learning». Оскільки деякі категорії мають англомовне походження, існують розбіжності в їх визначенні. Аналіз літературних джерел дозволяє зробити висновки, що деякі вчені ототожнюють терміни «відкрита освіта», «електронне навчання», «онлайнове навчання», «віртуальне навчання»; вважають терміни «відкрита освіта» та «неформальна освіта» синонімічними. Тому слід наголосити на різниці понять «відкрита освіта» та «дистанційна освіта» $\mathrm{i}$ 3'ясувати сутність цих термінів. Метою статті $є$ порівняльний аналіз відкритої та неформальної освіти.

Виклад основного матеріалу дослідження. У проєкті Стратегії сталого розвитку України до 2030 року [2] одним з пріоритетів є забезпечення інклюзивної та справедливої якісної освіти і сприяння можливостям навчатися впродовж усього життя для всіх. Так, 
разом $з$ такими завданнями, як забезпечення рівних можливостей для здобуття якісної початкової, базової та повної середньої освіти кожною дитиною; рівного та справедливого доступу до якісних систем розвитку, догляду та дошкільного навчання для всіх дітей; здобуття усіма учнями знань і навичок щодо принципів сталого розвитку; ліквідації гендерної нерівності у сфері освіти у документі прописано забезпечення рівного доступу до якісної освіти для всього населення, а також істотне збільшення кількості людей, які володіють суспільно необхідними навичками для отримання гідної роботи та занять підприємницькою діяльністю. У «Стратегії сталого розвитку Україна2020» [3] реформа освіти знаходиться у першочергових пріоритетах реалізації стратегії. Все це свідчить про підвищення уваги держави і суспільства загалом до відкритої освіти.

У відкритій освіті доступ до освітніх ресурсів забезпечується кожному бажаючому без перевірки вхідних параметрів знань (вступних іспитів), в якій використовуються технології (в тому числі дистанційні), що в максимальному ступені враховують бажання та можливості того, хто навчається. Суб'єктами (користувачами) таких освітніх послуг нерідко стають цілі сім'ї.

Відкрита освіта являє собою індивідуальний підхід до навчання, орієнтований на здійснення навчання кожного студента за індивідуальним планом. Відкрите навчання може включати дистанційну або інші форми навчання, а також можливість поєднувати елементи традиційного і самостійного навчання з відповідною формою контролю (табл.1).

Таблиця 1

Основні підходи до визначення сутності поняття «відкрита освіта»

\begin{tabular}{|c|c|}
\hline Aвmop & Визначення \\
\hline Биков В. [4] & $\begin{array}{l}\text { забезпечення на основі інформатизації освітнього простору свободи, } \\
\text { доступності вибору викладачів і студентів, гнучкості й } \\
\text { екстериторіальності навчання }\end{array}$ \\
\hline $\begin{array}{l}\text { Кейптаунська декларація } \\
\text { відкритої освіти } \\
\text { «Відкриваючи майбутнє } \\
\text { відкритим освітнім } \\
\text { ресурсам» [5] }\end{array}$ & $\begin{array}{l}\text { освіта, яка окрім відкритих освітніх ресурсів охоплює відкриті } \\
\text { технології, що сприяють співпраці та гнучким підходам до навчання, } \\
\text { відкритий обмін навчальними практиками для взаємозбагачення освітян, } \\
\text { нові підходи до оцінювання, акредитації та спільного навчання }\end{array}$ \\
\hline $\begin{array}{l}\text { Консорціум Відкритої } \\
\text { Освіти [6] }\end{array}$ & $\begin{array}{l}\text { ресурси, засоби і практики, які формують рамку відкритого } \\
\text { користування для покращання освітнього доступу та ефективності у } \\
\text { світовому вимірі }\end{array}$ \\
\hline Лещенко М., Яцишин А. [7] & $\begin{array}{l}\text { невід’ємна складова інформатизації суспільства, що відображає загальну } \\
\text { тенденцію послідовного переходу освітніх процесів із одного стану в } \\
\text { інший, формування визначального інформаційного і комунікаційного } \\
\text { базису розвитку освіти }\end{array}$ \\
\hline $\begin{array}{l}\text { Російський державний } \\
\text { інститут відкритої освіти }[8, \\
\text { с.10] }\end{array}$ & $\begin{array}{l}\text { гнучка система здобуття освіти, доступна кожному охочому, без аналізу } \\
\text { його освітнього цензу і регламентації періодичності і часу вивчення } \\
\text { окремого курсу, програми, яка розвивається на основі формалізації } \\
\text { знань, їх передачі і контролю } 3 \text { використанням інформаційних і } \\
\text { педагогічних технологій дистанційного навчання }\end{array}$ \\
\hline $\begin{array}{l}\text { Шотландська декларація } \\
\text { відкритої освіти [9] }\end{array}$ & $\begin{array}{l}\text { освіта, яка здатна розширити доступ до освіти, зробити участь ширшою, } \\
\text { створити нові можливості для майбутніх поколінь викладачів та учнів, } \\
\text { підготувати їх, щоб стати повністю цифровими громадянами, може } \\
\text { сприяти трансферу знань та активізувати якість і стійкість, забезпечуючи } \\
\text { соціальне включення, формуючи культуру міжінституційного } \\
\text { співробітництва та обміну }\end{array}$ \\
\hline Шуневич Б. [10] & $\begin{array}{l}\text { технологія навчання, яка побудована так, щоб навчання проходило } \\
\text { гнучким способом, незалежно від географічної віддаленості студента від } \\
\text { освітнього закладу, його соціальних і тимчасових обмежень }\end{array}$ \\
\hline
\end{tabular}


Дослідимо феномен відкритої освіти більш детально, для початку окресливши основні етапи іiї становлення: На першому, початковому етапі (70-80-ті роки XX століття) створено Відкритий Університет у Великій Британії у 1969 р., спостерігалося розповсюдження ідеї відкритої освіти передовими країнами світу. На другому, адаптаційному етапі (90-ті роки XX століття) різні міжнародні фонди здійснювали підтримку просвітницьких центрів, корегуючи їх діяльність під власне бачення. На третьому, масовому етапі (2000-ні роки - поточний час) з кожним роком зростала кількість користувачів ресурсів відкритої освіти. На четвертому, інституційному етапі за всіма ознаками розвитку суспільних відносин очікуємо в майбутньому перетворення відкритої освіти в загальний стандарт навчання за всіма рівнями. За всіма ознаками розвитку суспільних відносин очікуємо в майбутньому перетворення відкритої освіти в загальний стандарт навчання за всіма рівнями.

В.Биков виділяє три узагальнюючих чинники, що спричинили появу такого явища, як відкрита освіта. Перший чинник спричинений об'єктивними процесами розвитку суспільства, а саме: поява нових вимог до освітнього рівня людей, до характеру і темпів набуття ними освіти. Другий - пов'язаний з появою нових індивідуальних потреб в учнів щодо забезпечення свого особистісного розвитку та характеру отримання якісної освіти в сучасних умовах. Третій - спричинений тими об'єктивними процесами розвитку суспільства, які пов'язані з появою в системі освіти нових можливостей, що проявляються у розвитку змісту навчання і педагогічних технологій, у створенні додаткових умов для індивідуального особистісного розвитку людини, у поглибленні процесів демократизації та інтеграції освіти, а також у широкомасштабній інформатизації системи освіти, інших підсистем суспільства, з якими система освіти в процесі виконання своїх завдань так чи інакше взаємодіє. Зазначені чинники взаємообумовлені і взаємодоповнюють один одного. Нова освітня парадигма, що визначила і задекларувала принципи відкритої освіти, була реакцією системи освіти на зазначені чинники $[4$, с.46].

Оскільки стаття присвячена науковій систематизації теоретичних підходів до визначення понять «відкрита освіта» та «неформальна освіта», вважаємо доцільним перейти до наступного терміну (табл. 2).

Таблиця 2

Основні підходи до визначення сутності поняття «неформальна освіта»

\begin{tabular}{|l|l|}
\hline \multicolumn{1}{|c|}{ Автор } & \multicolumn{1}{|c|}{ Визначення } \\
\hline \multicolumn{1}{|c|}{1} & \multicolumn{1}{|c|}{2} \\
\hline $\begin{array}{l}\text { Глосарій основних термінів } \\
\text { професійної освіти [11, с. } \\
107]\end{array}$ & $\begin{array}{l}\text { будь-яка організована освітня діяльність поза рамками формальної } \\
\text { системи освіти, що забезпечує певні види навчання }\end{array}$ \\
\hline Гончарук А. [12] & $\begin{array}{l}\text { організована, структурована та цілеспрямована навчальна діяльність, } \\
\text { що здійснюєтья за межами закладів формальної освіти, спрямована на } \\
\text { задоволення найрізноманітніших освітніх потреб різних, у тому числі } \\
\text { вікових груп населення та не надає легалізованого диплома }\end{array}$ \\
\hline $\begin{array}{l}\text { Гусейнова Е., Лук'янова Ю. } \\
{[13]}\end{array}$ & $\begin{array}{l}\text { необов'язково має організований та систематичний характер, а також, } \\
\text { зазвичай, не передбачає присудження кваліфікацій і формального } \\
\text { оцінювання навчальних досягнень учасників }\end{array}$ \\
\hline $\begin{array}{l}\text { Європейський } \\
\text { розвитку професійної освіти } \\
{[14]}\end{array}$ & $\begin{array}{l}\text { навчання, засноване на запланованій діяльності, яка явно не позначена } \\
\text { як навчання (з точки зору завдань, тривалості навчання або підтримки } \\
\text { тих, хто навчається), але яка містить значимий навчальний елемент, } \\
\text { але зазвичай не завершується сертифікацією }\end{array}$ \\
\hline Кумбс Ф. [15] & $\begin{array}{l}\text { організована освітня діяльність поза встановленою формальною } \\
\text { системою, яка відбувається окремо як частина ширшої діяльності і має } \\
\text { цілі навчання }\end{array}$ \\
\hline
\end{tabular}


Продовження таблиці 2

\begin{tabular}{|c|c|}
\hline 1 & 2 \\
\hline Лук'янова Л. [16] & $\begin{array}{l}\text { освіта, що здійснюється в освітніх установах або громадських } \\
\text { організаціях (клубах, гуртках), під час індивідуальних занять } 3 \\
\text { репетитором, тренером й зазвичай не підтверджується наданням } \\
\text { документа }\end{array}$ \\
\hline $\begin{array}{ll}\text { Меморандум } & \text { безперервного } \\
\text { навчання } & \text { Свропейського } \\
\text { союзу [17] } & \\
\end{array}$ & $\begin{array}{l}\text { освіта, що зазвичай супроводжується видачою документа, } \\
\text { відбувається в навчальних закладах та громадських організаціях, а } \\
\text { також під час індивідуальних занять } 3 \text { репетитором або тренером }\end{array}$ \\
\hline МСКО 2011 (ЮНЕСКО) [18] & $\begin{array}{l}\text { інституціолізована, цілеспрямована і спланована особистістю або } \\
\text { організацією освіта, що забезпечує надання освітніх послуг }\end{array}$ \\
\hline $\begin{array}{lr}\text { Національний } & \text { інститут } \\
\text { стратегічних } & \text { досліджень } \\
\text { України [19] } & \\
\end{array}$ & $\begin{array}{l}\text { професійно спрямовані й загальнокультурні курси навчання в центрах } \\
\text { освіти дорослих, у лекторіях, по телебаченню, на різних курсах } \\
\text { iнтенсивного навчання }\end{array}$ \\
\hline $\begin{array}{l}\text { Національний } \quad \text { освітній } \\
\text { глосарій: вища освіта [20] }\end{array}$ & $\begin{array}{l}\text { додаткова освіта, що доцільно організована, проте не завершується } \\
\text { наданням кваліфікації певного рівня (етапу, циклу) формальної освіти }\end{array}$ \\
\hline Рада Свропи [21] & $\begin{array}{l}\text { цілеспрямоване та добровільне навчання, яке має місце в різних } \\
\text { умовах і ситуаціях, для яких навчання та підготовка необов'язково є } \\
\text { єдиним або основним видом діяльності }\end{array}$ \\
\hline Рекомендації СС [22] & $\begin{array}{l}\text { навчання, що відбувається у рамках планованої діяльності (щодо цілей } \\
\text { навчання, тривалості навчання), причому існує певна форма підтримки } \\
\text { при навчанні (наприклад, відносини «студент-викладач») }\end{array}$ \\
\hline Ройтблат О. [23] & $\begin{array}{l}\text { соціальна, динамічна, відкрита, варіативна, мобільна система, що } \\
\text { реагує на професійні потреби дорослої людини, по завершенню якої не } \\
\text { виникає будь-яких правових наслідків }\end{array}$ \\
\hline Сігаєва Л. [24] & $\begin{array}{l}\text { культурно-освітня робота } 3 \text { урахуванням потреб і інтересів слухачів } \\
\text { без отримання диплому }\end{array}$ \\
\hline Шапочкіна О. [18] & $\begin{array}{l}\text { будь-яка організована поза формальною освітою освітня діяльність, } \\
\text { що забезпечує засвоєння тих вмінь і навичок, що необхідні для } \\
\text { соціально та економічно активного громадянина країни. Ця освітня } \\
\text { діяльність структурована, має освітні цілі, визначені часові рамки, } \\
\text { інфраструктурну підтримку та проходить усвідомлено. Отриманні } \\
\text { знання звичайно не сертифікуються, хоча це можливо }\end{array}$ \\
\hline $\begin{array}{l}\text { Якушина М., Ілакавичус М., } \\
\text { Будай Л. [25] }\end{array}$ & $\begin{array}{l}\text { будь-яка організована систематизована діяльність, що проводиться за } \\
\text { межами формальної освітньої системи, для забезпечення заданих видів } \\
\text { навчання в інтересах тих, хто навчається }\end{array}$ \\
\hline
\end{tabular}

Джерело: систематизовано автором

В українському законодавстві зазначено, що неформальна освіта - це освіта, яка здобувається, як правило, за освітніми програмами та не передбачає присудження визнаних державою освітніх кваліфікацій за рівнями освіти, але може завершуватися присвоєнням професійних та/або присудженням часткових освітніх кваліфікацій [26]. Організація неформальної освіти є важливим соціально-політичним завданням діяльності більшості розвинених країн світу.

Аналіз вітчизняної та зарубіжної літератури з питань функціонування відкритої та неформальної освіти дозволяє відзначити такі спільні риси: безпосередній навчальний процес; індивідуалізація та особистісна спрямованість процесу навчання, адже людина навчається самостійно, практично не відволікаючись і має високий або достатньо високий рівень мотивації; інтеграція всіх способів засвоєння людиною світу; інтернаціональність та інтерактивність тощо. Слід зазначити, що основною метою як відкритої, так і неформальної освіти є приріст освітнього потенціалу, а основні ознаки обидва види відбуваються поза національною системою освіти і керуються актуальними 
потребами ринку. Поряд з цим слід визначити низку специфічних ознак кожного виду освіти (табл.3).

Таблиця 3

Специфічні риси відкритої та неформальної освіти

\begin{tabular}{|c|c|c|}
\hline Специффічні риси & Відкрита освіта & Неформальна освіта \\
\hline характер цілей & навчання відбувається протягом життя & короткострокові та специфічні \\
\hline документи & без отримання документів & без або з отриманням документів \\
\hline час & за бажанням слухача & $\begin{array}{l}\text { короткий цикл, неповний день, за } \\
\text { домовленістю }\end{array}$ \\
\hline зміст & $\begin{array}{l}\begin{array}{l}\text { задоволення цікавості } \\
\text { потреб }\end{array} \\
\end{array}$ & $\begin{array}{l}\text { індивідуально, орієнтація на результат, } \\
\text { практика, гнучкість }\end{array}$ \\
\hline контроль & самомотивація і самоконтроль & демократичний стиль, самоуправління \\
\hline місце & здебільшого Інтернет & різноманітні організації \\
\hline $\begin{array}{l}\text { нормативне } \\
\text { регулювання }\end{array}$ & відкритий доступ до ресурсів & навчання на договірній основі \\
\hline умови вступу & немає & $\begin{array}{l}\text { добровільно-договірна } \\
\text { зарахування }\end{array}$ \\
\hline форми & e-learning & $\begin{array}{l}\text { курси, гуртки, ГО, тренінги, репетитор, } \\
\text { майстерні, } \\
\text { семінари, пренінги, } \\
\end{array}$ \\
\hline мотивація & висока & достатньо висока або висока \\
\hline доступність & $\begin{array}{l}\text { для всіх незалежно від географічного } \\
\text { місця знаходження та матеріального } \\
\text { достатку }\end{array}$ & $\begin{array}{l}\text { місце знаходження i матеріальний } \\
\text { достаток, як правило, мають значення }\end{array}$ \\
\hline гнучкість & $\begin{array}{l}\text { здатність слухачів навчатись у зручний } \\
\text { час та у зручному місті }\end{array}$ & за домовленістю \\
\hline $\begin{array}{l}\text { непрямі } \\
\text { результати }\end{array}$ & $\begin{array}{l}\text { розвиток інформаційної культури в } \\
\text { суспільстві }\end{array}$ & $\begin{array}{lll}\begin{array}{l}\text { досягнення } \\
\text { організації }\end{array} & \text { цілей } & \text { керівництва } \\
\end{array}$ \\
\hline технологічність & $\begin{array}{lc}\text { використання } & \text { новітніх досягнень } \\
\text { інформаційних } \\
\text { технологій }\end{array}$ & може передбачати \\
\hline охоплення & $\begin{array}{l}\text { кількість споживачів не } є \text { критичним } \\
\text { параметром }\end{array}$ & $\begin{array}{llr}\text { навчання } & \text { здійснюється, коли } & \text { набрана } \\
\text { група } & \text { або воконані } & \text { умови } \\
\text { iндивідуального зарахування } & \\
\end{array}$ \\
\hline координова-ність & $\begin{array}{l}\text { залежить, як правило, лише від } \\
\text { бажання і можливості викладача / } \\
\text { організації передавати } \\
\text { децентралізована система }\end{array}$ & 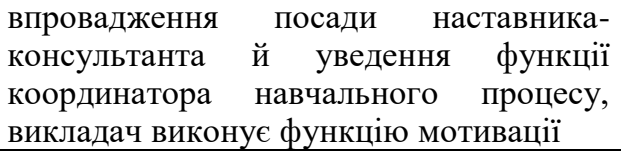 \\
\hline модульність & $\begin{array}{l}\text { можливість слухачу сформувати } \\
\text { індивідуальну навчальну програму, } \\
\text { яка складається } 3 \text { набору незалежних } \\
\text { курсів-модулів }\end{array}$ & за домовленістю \\
\hline паралельність & $\begin{array}{l}\text { полягає у здійсненні навчання } \\
\text { одночасно } 3 \text { професійною діяльністю, } \\
\text { без відриву від виробництва або } \\
\text { іншого виду діяльності }\end{array}$ & $\begin{array}{l}\text { може полягати у здійсненні навчання } \\
\text { одночасно } 3 \text { професійною діяльністю, } \\
\text { без відриву або } 3 \text { відривом від } \\
\text { виробництва або іншого виду діяльності }\end{array}$ \\
\hline віддаленість & 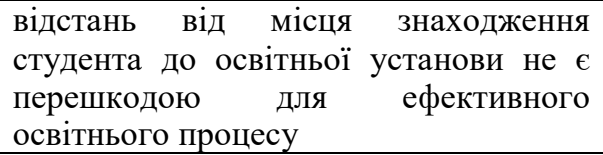 & може бути перешкодою \\
\hline асинхронність & $\begin{array}{l}\text { в процесі навчання студент і викладач } \\
\text { працюють за зручним для кожного } \\
\text { розкладом }\end{array}$ & за домовленістю \\
\hline економічність & + & не завжди \\
\hline $4 \mathrm{R}$ & $\begin{array}{l}\begin{array}{l}\text { право на перевикористання } \\
\text { перегляд }\end{array} \text { (reuse), } \\
\text { розповсюдження (redistribute) } \\
\text { переферо та }\end{array}$ & як правило, немає \\
\hline
\end{tabular}


Відкрита і неформальна освіта $є$ організованим навчанням. Якщо відкрита освіта $є$ завжди добровільною, то неформальна може здійснюватися за розпорядженням керівництва організації, де працює слухач. Відкрита освіта передбачає відкритий доступ до інформації, отже, є доступною для кожного, незалежно від рівня знань, матеріального стану, географічного місця перебування. Процес навчання при неформальній освіті пов'язаний 3 педагогічними цілями, при відкритій - доповнює інші складові частини навчання протягом усього життя, зокрема формальне навчання. Обидва види освіти надають перевагу компетентностям, які придбані активною участю в діяльності, повсякденному житті, але неформальна освіта більше спирається на досвід і дію й прагне до задоволення потреб учасників.

Для неформальної освіти є характерною орієнтація на конкретні освітні запити різних соціальних, професійних, демографічних груп населення, для відкритої піклування у відношенні до певних категорій осіб.

Високий особистісний сенс навчання та внутрішня відповідальність тих, хто навчається, за результат освітньої діяльності притаманні як неформальній, так і відкритій освіті. Слід зазначити, що відкрита і неформальна освіта мають схожі можливості та загрози (табл. 4).

\section{Відкрита та неформальна освіта: SWOT-аналіз}

Таблиця 4

\begin{tabular}{|c|c|c|}
\hline $\begin{array}{c}\text { Компоненти } \\
\text { аналізу }\end{array}$ & Неформальна освіта & Відкрита освіта \\
\hline $\begin{array}{l}\text { Сильні } \\
\text { сторони }\end{array}$ & $\begin{array}{l}\text { Законодавчо визначена, є достатньо } \\
\text { ресурсів, інформація про які } \\
\text { розповсюджується за допомогою } \\
\text { вірального маркетингу }\end{array}$ & $\begin{array}{l}\text { Є достатньо ресурсів, інформація про } \\
\text { які розповсюджується за допомогою } \\
\text { вірального маркетингу }\end{array}$ \\
\hline $\begin{array}{l}\text { Слабкі } \\
\text { сторони }\end{array}$ & $\begin{array}{l}\text { Недостатньо інтегрована в офіційно } \\
\text { визнану освіту }\end{array}$ & $\begin{array}{l}\text { Законодавчо не визначена, недостатньо } \\
\text { інтегрована в офіційно визнану освіту }\end{array}$ \\
\hline Можливості & $\begin{array}{l}\text { Зацікавленість місцевих громад, } \\
\text { збільшення кількості хоумскулерів } \\
\text { та мігрантів, зростання ролі освіти } \\
\text { протягом життя }\end{array}$ & $\begin{array}{l}\text { Створення центрів } 3 \text { метою } \\
\text { просвітницької діяльності та надання } \\
\text { освітніх послуг, зацікавленість } \\
\text { місцевих громад, збільшення кількості } \\
\text { хоумскулерів та мігрантів, зростання } \\
\text { ролі освіти протягом життя }\end{array}$ \\
\hline Загрози & $\begin{array}{lr}\text { Недостатньо } & \text { розроблена } \\
\text { нормативно-правова } & \text { база } \\
\text { функціонування } & \text { неформальної } \\
\text { освіти, можливе } & \text { ліцензування } \\
\text { освітньої діяльності } & \text { зменшить } \\
\text { активність тренінгових } & \text { центрів у } \\
\text { цьому секторі } & \end{array}$ & $\begin{array}{l}\text { Майже не розроблена нормативно- } \\
\text { правова база функціонування відкритої } \\
\text { освіти, фінансова криза може } \\
\text { спричинити зменшення донорського та } \\
\text { спонсорського інвестування }\end{array}$ \\
\hline
\end{tabular}

Джерело: розроблено автором

Дані соціологічного дослідження [27] показують, що значна кількість людей (71,4\%) вже проходили навчання черед Інтернет i достатньо активно до нього долучалися: 22,4\% навчалися 1-2 рази, 19,2\% - 3-4 рази, 18,2\% - 5-6 разів, 13,1\% - 7-10 разів. Така інтенсивність залученості до неформальної та відкритої освіти доводить важливість таких видів освіти у країні. Найбільш розповсюдженим каналом інформації, яким слухачі користуються у пошуку освітніх заходів, є соціальні мережі $(84,7 \%)$ та 
спеціалізовані Інтернет-ресурси $(48,7 \%) ; 39,2 \%$ респондентів за інформацією щодо освітніх заходів звертаються за рекомендаціями до друзів, а $32,5 \%$ респондентів мають досвід цілеспрямованого пошуку з цього питання. Щодо мети такого навчання - 74,2\% респондентів зазначили, що навчалися задля особистісного розвитку; 72,5\% - для підвищення рівня освіченості, розширення світогляду; 67,9\% - для підвищення професійної кваліфікації; 12,7\% - для отримання нової професії. Найбільшою перепоною участі в неформальної освіті респонденти визнали варіант відповіді «Не вистачає часу» - 58 \%, на другому місті - «Не вистачає грошей» - 51,4\%. Першу проблему можна вирішити при більш широкому впровадженні онлайн-форми навчання: а проблему нестачі грошей - через відкриту освіту.

Висновки 3 проведеного дослідження. У запропонованому дослідженні представлено спробу з'ясувати й аналізувати основні розуміння і тлумачення таких багатогранних понять, як «відкрита освіта» та «неформальна освіта». 3'ясовано, що ці явища стрімко розвиваються, а тому дещо змінюється і зміст понять.

У сучасній економіці зростає роль та значення нових знань. Крім того, наразі спостерігаємо жорстку конкуренцію за світовий ринок між деякими країнами, появу нових конкурентів, асиметрію світового господарства, про що говорять і нерівномірність розвитку певних галузей, і концентрація винаходів у технологічно розвинутих країнах світу. Таким чином, слід зробити висновок про суттєве підвищення ролі відкритої та неформальної освіти в умовах техноглобалізму, адже глобальна систему генерації наукових знань та ідей здатна вирівняти диспропорції на існуючих регіональних ринках освіти, забезпечити сталий інноваційний розвиток не лише нашої країни, а й суспільства загалом. Саме такі форми освіти створюють глобальне інформаційне освітнє середовище і є запорукою освітньої безпеки людства.

У статті доведено, що відкрита та неформальна освіта мають низку відмінностей. Так, при відкритій освіті навчання відбувається протягом всього життя, при неформальній освіті цілі мають короткостроковий та специфічний характер. Відкрита освіта, як правило, не передбачає отримання документа про здобуття певної компетентності, але деякі організації практикують підхід «тестування - сертифікація». При відкритій освіті слухач сам встановлює зручний для себе режим навчання, при неформальній - необхідна домовленість між суб'єктами освітнього процесу. Відкрита освіта задовольняє цікавість користувача, при неформальній освіті має місце «точкове вирішення проблем» 3 чіткою орієнтацією на результат. За умов відкритої освіти користувач самостійно мотивує і контролює себе, при неформальній освіті таку функцію, як правило, виконує тьютор. Відкрита освіта передбачає вільний доступ до ресурсів, неформальна освіта може передбачати плату за навчання або тестування при вступі (екзамени на «виході»). Слід зазначити, що відкриту освіту у більшості випадків можна розглядати як неформальну, однак у тому випадку, коли формальні організації (школи, технікуми, університети тощо) проводять відкриті заходи, такі як тренінги, профорієнтаційні школи тощо, відкрита освіта у цьому випадку розглядається як формальна, в той час як неформальна освіта не $\epsilon$ формальною. У той самий час неформальна освіта не завжди є відкритою, оскільки може передбачати: вступні іспити, оплату, підписання договору про права та обов'язки сторін тощо.

Практична значущість статті полягає у тому, що матеріали дослідження можуть бути використані науковцями i викладачами для подальшого організаційного та інфраструктурного забезпечення неформальної та відкритої освіти, а також для практикуючих фахівців соціальної роботи 3 мігрантами та опорними освітніми хоумскул-просторами. 


\section{СПИСОК ВИКОРИСТАНИХ ДЖЕРЕЛ}

1. Стадний Є. Українське студентство за кордоном: дані до 2017/18 навчального року [Електронний ресурс] / Доступ до ресурсу: https://cedos.org.ua/uk/articles/ukrainskestudentstvo-za-kordonom-dani-do-201718-navchalnoho-roku. - Назва з екрану.

2. Стратегія сталого розвитку України до 2030 року [Електронний ресурс] / Доступ до pecypcy: https://www.undp.org/content/dam/ukraine/docs/SDGreports/UNDP_Strategy_v06optimized.pdf. - Назва з екрану.

3. Стратегія сталого розвитку «Україна-2020» [Електронний ресурс] / Доступ до ресурсу: https://zakon1.rada.gov.ua/laws/show/5/2015. - Назва з екрану.

4. Биков В.Ю. Моделі організаційних систем відкритої освіти: монографія / В.Ю. Биков. - К.: Атіка, 2008. - 250 с.

5. The Cape Town Open Education Declaration. [Електронний ресурс] / Доступ до ресурсу: http://www.capetowndeclaration.org/. - Назва з екрану.

6. Global Education Consortium. Global Network for Open Education. [Електронний ресурс] / Доступ до ресурсу: http://www.oeconsortium.org/. - Назва з екрану.

7. Лещенко М. П. Відкрита освіта у категоріальному полі вітчизняних і зарубіжних учених / М.П.Лещенко, А.В.Яцишен // Інформаційні технології і засоби навчання. - Т. 39, Вип. 1, с. 1-16.

8. Відкрита освіта: Колективний розвиток освіти через відкриті технології, відкритий контент і відкрите знання. За ред. Тору Іійосі та М.С.Віджая Кумара / переклад з англ. А. Іщенка та О. Насика. - К.: Наука, 2009. - 256 с.

9. Scottish Open Education Declaration. Open Scotland. [Електронний ресурс] / Доступ до pecypcy: http://openscot.net/declaration/. - Назва з екрану.

10. Шуневич Б. Обгрунтування наукової термінології з дистанційного навчання / Б.Шуневич // Вісник Національного університету. — 2003. - № 490. - С. 95-104.

11. Глосарій основних термінів професійної освіти / упоряд. Т. М. Десятов / за заг. ред.

Н. Г. Ничкало. - К. : Вид-во Артек, 2009.

12. Гончарук А. Неформальна освіта дорослих у країнах СС. - Педагогічні науки. - 2012.

- №54. - С.31-36.- [Електронний ресурс] / Доступ до pecypcy: http://nbuv.gov.ua/UJRN/pena_2012_54_8. - Назва з екрану.

13. Гусейнова Е.I. Неформальна освіта як важливий елемент безперервної освіти / Е.I. Гусейнова, Ю.М. Лук'янова // Педагогічні науки - 2012. [Електронний ресурс]. - Доступ до ресурсу: http://www.rusnauka.com/11_NPE_2012/Pedagogica/4_106261.doc.htm. Назва з екрану.

14. Терьохіна Н.О. Неформальна освіта як важлива складова системи освіти дорослих / Н.О. Терьохіна Н.О. // Порівняльно-педагогічні студії. - 2014. - № 2/3.- С.109-114.

15. Coombs P. Ahmed M. Attacking rural poverty; how nonformal education can help. [Електронний ресурс] - Доступ до ресурсу: http://wwwwds.worldbank.org/external/default/WDSContentServer/WDSP/IB/2000/02/18/000178830_9 8101911003 374/Rendered/PDF/multi_page.pdf. - Назва з екрану.

16. Лук'янова Л.Б. Неформальна освіта дорослих: проблеми і перспективи. - Професійна освіта: педагогіка і психологія: пол.-укр., укр.-пол.щорічник / за ред. Т.Левовицького, І.Вільш, І.Зязюна, Н.Ничкало - Ченстохова; Київ, 2011. - № 13. - С. 327-333.

17. A Memorandum on Lifelong Learning - [Електронний ресурс] - Доступ до ресурсу: http://arhiv.acs.si/dokumenti/Memorandum_on_Lifelong_Learning.pdf. - Назва з екрану.

18. Горленко В.М. Неформальна освіта як чинник розвитку інформаційнокомунікаційної компетентності вихователів дошкільного навчального закладу / В.М. 
Горленко // Науковий вісник Ужгородського університету. Серія Педагогіка. Соціальна робота. - 2017. - №1(40). - С. 67-73.

19. Освіта протягом життя: світовий досвід і українська практика. Аналітична записка [Електронний ресурс]. - Доступ до ресурсу: http://www.niss.gov.ua/articles/252/. - Назва 3 екрану.

20. Національний освітній глосарій: вища освіта / авт.-уклад. : І. І. Бабин, Я. Я. Болюбаш, А. А. Гармаш [та ін.]; за ред. Д. В. Табачника, В. Г. Кременя. - К. : ТОВ Вид. дім Плеяди, 2011.

21. The European Knowledge Centre for Youth Policy. - [Електронний ресурс] - Доступ до pecypcy: http://pjp- eu.coe.int/en/web/youth-partnership/glossary. - Назва з екрану.

22. Рекомендація Ради ЄС щодо визнання неформального та інформального навчання. [Електронний ресурс] - Доступ до ресурсу: http://ipq.org.ua/upload/files/files/06_Biblioteka/01_Normativna_baza/01_Viznznnya_neform alnogo_nav

channya/01_Mignarodni_dokumenti/council_recommendations_20_dec_2012_ukr.pdf. _Назва з екрану.

23. Ройтблат О.В. Развитие неформального образования в современном оциокультурном пространстве России / О.В. Ройтблат // Человек и образование. - 2013. - № 1. - С. 25-28. 24. Сігаєва Л. Є. Характеристика структури освіти дорослих в сучасній Україні / Л.Є. Сігаєва // Вісник Житомирського державного університету. - 2011. - № 59 - С. 38-42.

25. Якушина М.С. Диверсификация маршрутов неформального образования для разновозрастных сообществ в условиях развития СНГ / М.С. Якушина, М.Р. Илакавичус, Л.П. Будай // Человек и образование. - 2013. - № 3. - С. 68-71.

26. Про освіту: Закон України від 5.09.2017 № 2145-VIII. Дата оновлення: 6.06.2019. [Електронний ресурс] - Доступ до ресурсу: https://zakon.rada.gov.ua/laws/show/2145-19. Назва з екрану.

27. Москаленко Л.М. Тенденції розвитку неформальної освіти в Україні (за результатами соціологічного дослідження) / Л.М. Москаленко // Вісник Львівського університету. Серія соціол. 2018. - Вип.12. - С.212-220. 